\title{
Microbial deterioration of lamb meat from European local breeds as affected by its intrinsic properties
}

\author{
Ursula Gonzales-Barron $^{\mathrm{a}}{ }^{*}$, Sara Coelho-Fernandes ${ }^{\text {a }}$, Gisela Santos-Rodrigues ${ }^{\text {a }}$, \\ Altino Choupina ${ }^{\mathrm{a}}$, Roberto Bermúdez Piedra ${ }^{\mathrm{b}}$, Koldo Osoro ${ }^{\mathrm{c}}$, Rafael Celaya ${ }^{\mathrm{c}}$, Rocío R. García ${ }^{\mathrm{c}}$, \\ Tanja Peric ${ }^{\mathrm{d}, \mathrm{e}}$, Silvia Del Bianco ${ }^{\mathrm{e}}$, Edi Piasentier ${ }^{\mathrm{e}}$, Francesco Chiesa ${ }^{\mathrm{f}}$, Alberto Brugiapaglia ${ }^{g}$, \\ Luca Battaglini $^{\mathrm{g}}$, Mario Baratta ${ }^{\mathrm{f}}$, Raúl Bodas ${ }^{\mathrm{h}}$, José M. Lorenzo ${ }^{\mathrm{b}, \mathrm{i}}$, Vasco A.P. Cadavez ${ }^{\mathrm{a}}$ \\ ${ }^{\text {a }}$ Centro de Investigação de Montanha (CIMO), Instituto Politécnico de Bragança, 5300-253, Bragança, Portugal \\ ${ }^{\mathrm{b}}$ Centro Tecnológico de la Carne de Galicia, Rúa Galicia No 4, Parque Tecnológico de Galicia, San Cibrao das Viñas, 32900, Ourense, Spain \\ ${ }^{\mathrm{c}}$ Servicio Regional de Investigación y Desarrollo Agroalimentario (SERIDA), Ctra. de Oviedo $s / n$., 33300, Villaviciosa, Asturias, Spain \\ ${ }^{\mathrm{d}}$ Laboratory for Environmental and Life Sciences, University of Nova Gorica, Nova Gorica, Slovenia \\ ${ }^{\mathrm{e}}$ Department of Agricultural, Food, Environmental and Animal Sciences, Università degli Studi di Udine, Udine, Italy \\ ${ }^{\mathrm{f}}$ Department of Veterinary Science, Università degli Studi di Torino, Turin, Italy \\ ${ }^{\mathrm{g}}$ Department of Agricultural, Forest and Food Sciences (DISAFA), Universitá degli Studi di Torino, Turin, Italy \\ ${ }^{\mathrm{h}}$ Instituto Tecnológico Agrario de Castilla y León, Leon, Spain \\ i Área de Tecnología de los Alimentos, Facultad de Ciencias de Ourense, Universidad de Vigo, 32004, Ourense, Spain
}

\section{A R T I C L E I N F O}

\section{Keywords:}

Sheep

Autochthonous breeds

Proximate composition

Lactic acid bacteria

Pseudomonas

Psychrotrophic bacteria

\begin{abstract}
A B S T R A C T
Although sheep meat has a small share of $\sim 1.5 \%$ of the total meat production in the EU, sheep farming is of great importance to rural development and the environment. Enhancing the quality of lamb meat of local breeds is essential to ensure both profitability for sheep producers and the conservation of endangered breeds. This study aimed to (i) characterise the evolution of spoilage microorganisms in refrigerated vacuum-packed lamb meat from a total of 10 farms housing 8 local breeds of Portuguese, Spanish, Italian and Slovenian origin raised in intensive, extensive or semi-extensive regime; and (ii) elucidate how intrinsic properties of meat can affect its microbial spoilage. Cold carcass weight (CCW), ultimate $\mathrm{pH}\left(\mathrm{pH}_{24}\right)$ and proximate analysis were quantified on carcass/meat from each of the 285 animals raised and slaughtered for this purpose; while mesophiles, lactic acid bacteria, Pseudomonas spp. and psychrotrophic bacteria were enumerated during 15-day storage at $4{ }^{\circ} \mathrm{C}$. Substantial variability in all attributes were found between the ten farms. CCW of intensively-raised lambs $(21.4 \mathrm{~kg}$; $95 \% \mathrm{CI}: 20.6-22.1 \mathrm{~kg})$ were higher $(\mathrm{p}<0.05)$ than the ones in semi-extensive regime $(14.9 \mathrm{~kg}$; $95 \% \mathrm{CI}$ : $14.4-15.4 \mathrm{~kg})$, and in turn these were heavier $(\mathrm{p}<0.05)$ than the extensively raised lambs $(12.4 \mathrm{~kg} ; 95 \% \mathrm{CI}$ : 12.0-12.7). Mean contents of protein (76.5-87.4\% db), fat (3.78-13.1\% db) and ashes (4.62-5.65\% db) in lamb meat were highly dependent on the farm. Although meat from some farms was associated to higher microbial levels, in general, microbial growth was found to be modulated by intrinsic properties of meat. Higher $\mathrm{pH}_{24}(\mathrm{p}<$ $0.05)$, moisture $(\mathrm{p}<0.05)$, protein content $(\mathrm{p}<0.05)$ and ashes content $(\mathrm{p}<0.01)$ accelerated spoilage rate; whereas meat from heavier carcasses $(\mathrm{p}<0.001)$ and of higher fat content $(\mathrm{p}<0.01)$ presented slower growth of spoilage bacteria. In order to improve the microbial quality of lamb meat, animal handling must be enhanced to minimise pre-slaughter stress; slaughtering practices and hygiene must be improved; and a carcass classification system could be adopted towards the selection of fatter animals and chilled carcasses of optimal $\mathrm{pH}_{24}$.
\end{abstract}

\section{Introduction}

Sheep farming is an activity of economic importance as these animals are sources of meat, milk, wool and fur. In the European Union (EU), there are approximately 83 million sheep, which are often raised in economically vulnerable areas such as mountain regions, with nearly two thirds of the animals distributed in the UK (26.3\%), Spain (18.5\%), Romania (11.9\%) and Greece (9.9\%) (Eurostat, 2019). With regards to

\footnotetext{
* Corresponding author.

E-mail address: ubarron@ipb.pt (U. Gonzales-Barron).
} 
meat production, sheep meat has a share of only $\sim 1.5 \%$ in the EU (Eurostat, 2019), with an aproximate level of self-sufficiency of $85 \%$ (Statista, 2020). There is considerable variation in the production systems employed within and across the different bio-geographic regions of Europe, which are heavily influenced by land type. In addition, there are a vast range of sheep breeds used and a wide range of management practices adopted, all of which make sheep farming enormously rich in diversity (Anonymous, 2000). Many of those breeds are native: for example, in Spain there are $\sim 50$ different sheep breeds, of which 42 are native and 32 are at risk of becoming extinct (de-Arriba and Sánchez-Andrés, 2014).

Such threats facing European sheep breeds have been prompted by intensive production and increased commercial demands, causing production to focus on only a few breeds, to the detriment of rare or minority breeds (Lawson Handley et al., 2007). However, the indigenous sheep breeds, in addition to contributing to the diversity of production systems, are important genetic resources that must be preserved because of their local adaptation, disease resistance, high fertility and unique product qualities (Mendelsohn, 2003). Some of these breeds, classified as threatened, have small body size and good adaptation to adverse environments (climate and orography), which makes them particularly well suited to the use and enhancement of natural pastures (Cruz et al., 2019).

Although sheep farming represents only a small contribution to Europe's gross domestic product, the sector is of great importance to rural development and the environment. Furthermore, the loss of diversity in domestic species has important economic, ecological and social implications (Lawson Handley et al., 2007). As de-Arriba and Sánchez-Andrés (2014) point out, the sheep farming sector must be sustained by two actions: (i) extended mechanisms of support provided by public authorities to assure the maintainance of the activity in the sector and the promotion of internal consumption; and (ii) increased added value through quality, and the development of named origin and ecological products. It is therefore understood that enhancing the quality of meat from autochthonous breeds, making it more attractive to consumers, is essential to ensure a good income level for sheep producers. This could contribute to the preservation of the rural world and its diversity, the conservation of endangered breeds, and the improvement of the living standards of the sheep farmers that remain in the rural areas of Europe.

Meat quality is a multifactorial concept regulated by factors that are intrinsic and extrinsic to the animal. On the one hand, quality is perceived by the consumer through good sensorial properties - optimised through cold maturation. Yet, on the other hand, the producer must not only meet such organoleptic demands, but must also ensure that the product remains microbiologically safe during its shelf life, which should aim to be the longest possible to avoid economic losses (Mills et al., 2014). In the case of lamb meat, after 7 days of maturation $\sim 80 \%$ of its maximum tenderness potential is reached (Prates, 2000). However, during this maturation, microbial deterioration takes place due to the proliferation of psychrotrophic bacteria, lactic acid bacteria, Pseudomonas spp., Clostridium spp., etc. (Clemens et al., 2010). One of the well-known strategies to prolong the shelf life of the meat is vacuum packaging, which can moderately retard microbial deterioration. However, the extent of such retardation depends on chilling system/profile, initial microbial contamination and the physicochemical or intrinsic properties of meat.

Therefore, the objective of this study was twofold: (i) to evaluate the evolution of spoilage indicator microorganisms (mesophiles, psychrotrophic, lactic acid bacteria and Pseudomonas spp.) in refrigerated vacuum-packed (VP) lamb meat originating from 10 farms housing 8 European breeds raised in intensive, extensive or semi-extensive regime; and (ii) to elucidate, by means of mixed models, any interrelationship between meat's intrinsic properties (i.e., $\mathrm{pH}$, water activity, moisture content, fat content, protein content and ashes) and microbial growth.

\section{Methodology}

\subsection{Lamb rearing and feeding}

Eight sheep breeds exploited for meat production were utilised in the present study: Churra-Galega-Bragançana (CGB) and Bordaleira-deEntre-Douro-e-Minho (BEDM), from the Mediterranean and the Atlantic bioregions of Portugal, respectively; Castellana and INRA401 from the Mediterranean bioregion of Spain; Gallega from the Atlantic bioregion of Spain; Biellese and Sambucana from the Continental and the Alpine bioregions of Italy, respectively; and Jezersko-Solčavska (JSO) from the Alpine bioregion of Slovenia.

\subsubsection{Portugal}

In the Mediterranean region, located in Bragança, CGB lambs were raised on the holding of the School of Agriculture of the Polytechnic Institute of Bragança. In the Atlantic bioregion, located in Ponte de Lima, BEDM lambs were raised on the holding of the Ponte de Lima Agrarian School. The production system used for BEDM lambs was the extensive one, while for CGB lambs the semi-extensive system, whose feeding was based on grazing on natural pastures. The hours of grazing varied according to hours of light, heat and herd size. In winter, the flocks would be released in the morning to graze all day until dark. In the summer, the herds would leave at dawn and graze until midmorning, then they would be put in a stable under shade, and would come out when the heat had subsided. Once on the premises, all lambs had access to meadow hay and water ad libitum, but the semi-extensively raised lambs were also supplemented with protein and mineral-rich concentrates. The lambs were not weaned, and were reared in the fall of 2018 and spring 2019. For this investigation, 15 BEDM and 15 CGB lambs were reared in 2018 and 15 BEDM and 15 CGB lambs were reared in 2019.

\subsubsection{Spain}

In the Mediterranean regions of Salamanca (for INRA401 breed) and Zamora (for Castellana breed), lambs were raised under an intensive system on commercial farms. Lambs were weaned when they were 4-6 weeks old and housed with straw bedding and free access to commercial concentrate, cereal straw and fresh water. In the Mediterranean region, located in Valladolid, Castellana breed lambs were raised under a semiextensive system. Animals were weaned at 4-6 weeks old and housed together with straw bedding, allowed to graze outdoors (pastures were predominately oak and pine forests, cereal stubbles and vineyards) during the mornings; animals were kept indoors during the afternoon and night, with free access to commercial concentrate, cereal straw and fresh water. Fourteen INRA401 and 15 Castellana (from Zamora) lambs were reared in the spring of 2018, while 30 Castellana lambs (15 from Zamora and 15 from Valladolid) were reared in the spring of 2019.

In Asturias (northern Spain, Atlantic bioregion), lambs were reared with their dams at the SERIDA experimental farm located in Grado. Lambs of Gallega breed were born during winter, grown suckling their mothers on pasture, and weaned in late spring-early summer before their slaughter at an age of 4-5 months. Lambs (36 in 2018, 48 in 2019) were raised in an extensive system on 12 experimental paddocks (half with apple trees) sown with perennial ryegrass (Lolium perenne) and white clover (Trifolium repens) and organically managed (without synthetic fertilisers), where grazing season started in early April. In 2019, another lot of 12 lambs were managed in a semi-extensive system on pasture supplemented with concentrate feeding offered in troughs since late April.

\subsubsection{Italy}

In the Continental bioregion, located in Turin (North West of Italy), Biellese lambs were raised in CISRA, Teaching Animal Farm of the Veterinary Science Department, University of Turin. In the Alpine bioregion, located in Val Maira (CN), Western Alps, at an altitude of 
1800-2000 m, Sambucana lambs were bred during the summer season. The production system used for Biellese breed was semi-extensive (i.e., the lambs consumed about $500 \mathrm{~g}$ of milk per day, after weaning (day 60 ), they were fed with $\sim 150 \mathrm{~g}$ of concentrate per day and hay ad libitum until the slaughtering) while the production system for Sambucana lambs was based on grazing on natural pasture. In the semi-extensive system for Biellese lambs, the flocks would be released to graze outside in autumn-winter season (period of investigation); whereas in the extensive system, Sambucana lambs would leave at dawn and graze until evening, then they would be recovered in a fence in summer season (period of investigation). The lambs were not weaned during the grazing season in the Alpine bioregion. For this investigation, 16 Biellese and 20 Sambucana lambs were reared in 2018, and 12 Biellese and 12 Sambucana lambs were reared in 2019.

\subsubsection{Slovenia}

In the Alpine region, located near Tolmin (Slovenia), autochthonous Jezersko-Solčava (JSO) lambs were raised extensively on a farm with a flock of around 30 ewes. The lambs, born at the farm, were not weaned but reared with their dams until slaughtered. Until the end of November the flock was kept on a free Alpine lowland pasture utilizing a rotational grazing system without any feed supplementation. After that, they were kept free in a stable with an outdoor area available for grazing. While stabled, they were fed ad libitum with meadow hay. Additional rations of a feed mixture with vitamins and minerals for lambs were offered in an average daily amount of $100 \mathrm{~g}$ per animal. In the stable, the lambs had water ad libitum. For this investigation, 15 JSO lambs born in autumn 2017 and 15 JSO lambs born in autumn 2018 were reared. The investigation was conducted in nature under the usual conditions for rearing and management of the flock.

\subsection{Preparation of lamb meat samples}

All lambs were four-to-five months old when slaughtered. Lambs were slaughtered in batches ranging from 5 to 12 animals in local abattoirs of Portugal, Spain, Italy and Slovenia, and the whole experiment was conducted in the fall and spring seasons of 2017 (Slovenia only), 2018 and 2019. During slaughter, lamb carcasses were randomly monitored by a veterinarian inspector. A total of 285 lambs were employed in this study, from the following breeds and production systems: BEDM extensive (28), Biellese semi-extensive (28), Castellana intensive (30), Castellana semi-extensive (15), CGB semi-extensive (30), Gallega extensive (74), Gallega semi-extensive (12), INRA401 intensive (14), JSO extensive (22) and Sambucana extensive (32).

In the slaughterhouses, carcasses obtained were chilled at $4{ }^{\circ} \mathrm{C}$, and cold carcass weight (CCW) was registered after $24 \mathrm{~h}$. After carcass splitting, the Longissimus dorsi muscle was removed from the 6th to the 13th vertebra under aseptic conditions. The left side was divided into three parts. Each of them was vacuum packed in transparent gas-tight polyamide and polyethylene vacuum bags (Orved $\AA$, Spain, with permeability of $84 \pm 4.20 \mathrm{cc} / \mathrm{m}^{2} / 24 \mathrm{~h} / \mathrm{atm}$ for $\mathrm{O}_{2}, 361 \pm 18.05 \mathrm{cc} / \mathrm{m}^{2}$ / $24 \mathrm{~h} / \mathrm{atm}$ for $\mathrm{CO}_{2}, 22 \pm 1.10 \mathrm{cc} / \mathrm{m}^{2} / 24 \mathrm{~h} / \mathrm{atm}$ for $\mathrm{N}_{2}$ and $9.0 \pm 0.45 \mathrm{cc} /$ $\mathrm{m}^{2} / 24 \mathrm{~h} / \mathrm{atm}$ for $\mathrm{H}_{2} \mathrm{O}$ and density of $\pm 100 \mu \mathrm{m}$ ); labelled with the number 3,9 or 15 , corresponding to the day of microbiological analysis; and stored at $4 \pm 0.5{ }^{\circ} \mathrm{C}$ in calibrated laboratory incubators. Concentrations of total viable counts, psychrotrophic bacteria, lactic acid bacteria (LAB) and Pseudomonas spp. were determined in duplicate at each time point. The right half of the $L$. dorsi muscle was kept for the physicochemical analyses - $\mathrm{pH}$, water activity, moisture and dry matter, fat content, protein content and ash content - which were carried out on day 1 after slaughter. Unlike microbiological analyses, the intrinsic properties of meat (physicochemical analyses) were essayed right at the beginning of the cold maturation, except for water activity which was measured on day 3 .

\subsection{Microbiological and physicochemical analyses}

All methods for microbiological and physicochemical analyses were harmonised between laboratories. For the microbiological analyses, $25 \mathrm{~g}$ of meat were homogenised in $225 \mathrm{~mL}$ of buffered peptone water (611014 Liofilchem, Roseto degli Abruzzi, Italy) for $1 \mathrm{~min}$ (Interscience Bag Mixer 400, France). One-ml aliquots from decimal dilutions were inoculated on Aerobic Count Plate petrifilms (3M, MN, USA) for counting of mesophiles, and on Lactic Acid Count Plate petrifilms (3M, MN, USA) for counting of LAB. One-ml aliquots were plated by incorporation in Plate Count Agar (610040 Liofilchem, Roseto degli Abruzzi, Italy) for the determination of psychrotrophic bacteria, while, for the quantification of Pseudomonas, $0.5-\mathrm{mL}$ aliquots were spread onto Pseudomonas Agar Base (CM0559 Oxoid, Thermo Fisher Scientific, UK), added with $1 \% \mathrm{v} / \mathrm{v}$ glycerol and supplemented with cetrimide-fucidinecephalosporin (610071 Liofilchem, Roseto degli Abruzzi, Italy). The mesophilic and LAB plates were incubated at $35 \pm 0.5^{\circ} \mathrm{C}$ for $48 \mathrm{~h}$; the psychrotrophic bacteria plates at $7 \pm 0.5{ }^{\circ} \mathrm{C}$ for 11 days; and the Pseudomonas plates at $25 \pm 0.5^{\circ} \mathrm{C}$ for $48 \mathrm{~h}$. Plating was done in duplicate, and colony counts were transformed to $\log \mathrm{CFU} / \mathrm{g}$.

The meat's intrinsic properties measured were ultimate $\mathrm{pH}\left(\mathrm{pH}_{24}\right)$, water activity $\left(\mathrm{a}_{\mathrm{w}}\right)$ and proximate composition. The $\mathrm{pH}$ measurement was carried out according to Pateiro et al. (2013), using a pH meter (HI 99163, Hanna Instruments, Eibar, Spain) equipped with a 232D glass penetration probe. To measure $\mathrm{a}_{\mathrm{w}}$, lamb steaks were cut to exactly fit in the cuvette of the Aqualab meter (4TE Decagon, USA). $a_{w}$ was recorded after measurement stabilisation. Moisture, fat, protein and ashes contents were determined according to ISO (1997); AOCS (2005); ISO (1978) and ISO (1998), respectively. Determinations were made in triplicate per meat sample. Contents of fat, protein and ashes were expressed in dry basis.

\subsection{Statistical analysis}

The statistical analysis aimed to understand to what extent the CCW and the intrinsic properties of meat (i.e., $\mathrm{pH}, \mathrm{a}_{\mathrm{w}}$ and proximate composition) can affect or modulate its microbial spoilage, as characterised by the change in the populations of mesophiles, LAB, psychrotrophic bacteria and Pseudomonas spp.

A general mixed-effects model of the type,

$Y_{r(j)}=\beta_{0 r(j)}+\beta_{1 r(j)}$ Day $+\beta_{2}(X)($ Day $)+\beta_{3}$ Day $^{2}+\varepsilon_{r(j)}$

$\beta_{0 r(j)}=\beta_{0}+u_{0 r}+v_{0 r(j)}$

$\beta_{1 r(j)}=\beta_{1}+u_{1 r}+v_{1 r(j)}$

was adjusted to each of the microbial groups $(Y)$ to assess the effect of time of maturation (Day) and each of the intrinsic properties of meat $(X)$, in separate. The response variable $Y_{r(j)}$ is the microbial concentration in the meat sample from lamb $j$ belonging to farm $r$, measured after maturation time Day. A sheep farm is defined by a local breed raised under certain production system, which amounted to 10 farms in this study: BEDM - extensive, CGB - semi-extensive, Castellana - intensive, Castellana - semi-extensive, Gallega - extensive, Gallega - semiextensive, INRA401 - intensive, Biellese - semi-extensive, Sambucana - extensive, and JSO - extensive.

The mean intercept $\beta_{0}$ is affected by random shifts $u_{0 r}$ caused by the farm $r$ and $v_{0 r(j)}$ caused by the lamb $j$ within farm $r$. The parameter $\beta_{1 r(j)}$ is the fixed effect of maturation time on the microbial concentration, yet it is specific to the lamb $j$ nested within farm $r$. Therefore, random shifts $u_{1 r}$ caused by the farm $r$ and $v_{1 r(j)}$ caused by the lamb $j$ belonging to farm $r$ were set to affect the time slope $\beta_{1}$. This model allows the effect of maturation time to be modulated by the intrinsic property $X$, so the parameter $\beta_{2}$ assesses this interaction. Thus, a significant interaction term $\beta_{2}$ would signify that the intrinsic property $X$ under study tends to accelerate or disaccelerate the growth rate of the microorganism $Y$ in the refrigerated VP meat. A quadratic effect for Day $\left(\beta_{3}\right)$ was added given its 
significance in all models. Intercept and slope random effects were assumed to be correlated, and to follow normal distributions. The residuals $\varepsilon_{r(j)}$ are assumed to follow a normal distribution.

Eq. (1) was adjusted separately to each of the four microbial groups $(Y)$, and, in each of the adjustments, the independent variable $X$ represents CCW, $\mathrm{pH}_{24}, \mathrm{a}_{\mathrm{w}}$, moisture, protein, fat or ashes content. Thus, in total 28 models were fitted. Nonetheless, these models were not intended for predicting microbial concentrations in time, but for inferring both the effects of the intrinsic properties of meat on bacterial growth, and the differences between sheep farms. The effect of an intrinsic property of meat on the rate of microbiological deterioration was assessed by the significance of the parameter $\beta_{2}$, and the p-value of its respective F-test in analysis of variance (ANOVA); whereas the differences in microbial load between sheep farms were assessed by the random effects of the model's intercept $\left(u_{0 r}\right)$ and time slope $\left(u_{1 r}\right)$. The models were adjusted in the R software (The R Core Team, 2019).

\section{Results and discussion}

If lamb is produced under good manufacturing practices, the initial counts of mesophilic microorganisms on the meat surface is likely to be $\sim 10^{3} / \mathrm{cm}^{2}$ or lower (Mills et al., 2014). In our experiments, the abattoirs' controlled process hygiene ensured that the bacterial counts in VP meat were relatively low still on the third day after slaughter, at mean values of $2.28 \mathrm{log}$ CFU/g for mesophiles, $1.18 \mathrm{log} \mathrm{CFU} / \mathrm{g}$ for LAB, 2.36 $\log \mathrm{CFU} / \mathrm{g}$ for psychrotrophic bacteria and $1.55 \mathrm{log} \mathrm{CFU} / \mathrm{g}$ for Pseudomonas spp. (Fig. 1). By contrast, the mesophiles level determined by Wang et al. (2019) in VP lamb meat on the third day of storage was much higher at $4.95 \log \mathrm{CFU} / \mathrm{g}$ despite the comparable storage temperature of $4-6{ }^{\circ} \mathrm{C}$.

Nonetheless, our work registered a considerable variation in microbial levels among farms (i.e., breeds in production systems). On day 3 , the counts of mesophiles, $\mathrm{LAB}$ and psychrotrophic bacteria in lamb meat varied from 1.39 to $3.47 \log \mathrm{CFU} / \mathrm{g}$, from 0.79 to $2.37 \log \mathrm{CFU} / \mathrm{g}$, and from 1.22 to $4.01 \log \mathrm{CFU} / \mathrm{g}$, respectively. The lowest counts belonged to meat of CGB origin and the highest ones to that of JSO origin (Fig. 1). The level of Pseudomonas spp. in lamb was also variable, with meat from the Biellese breed farm presenting the lowest mean value (0.77 log CFU/ $\mathrm{g})$, and meat from the Castellana breed farms the highest one $(2.45 \mathrm{log}$ $\mathrm{CFU} / \mathrm{g}$ ). The lowest initial microbial populations were found for Pseudomonas and LAB. Since vacuum packaging excludes oxygen, the strictly aerobic rapidly-growing Pseudomonas are inhibited. Mills et al. (2014)
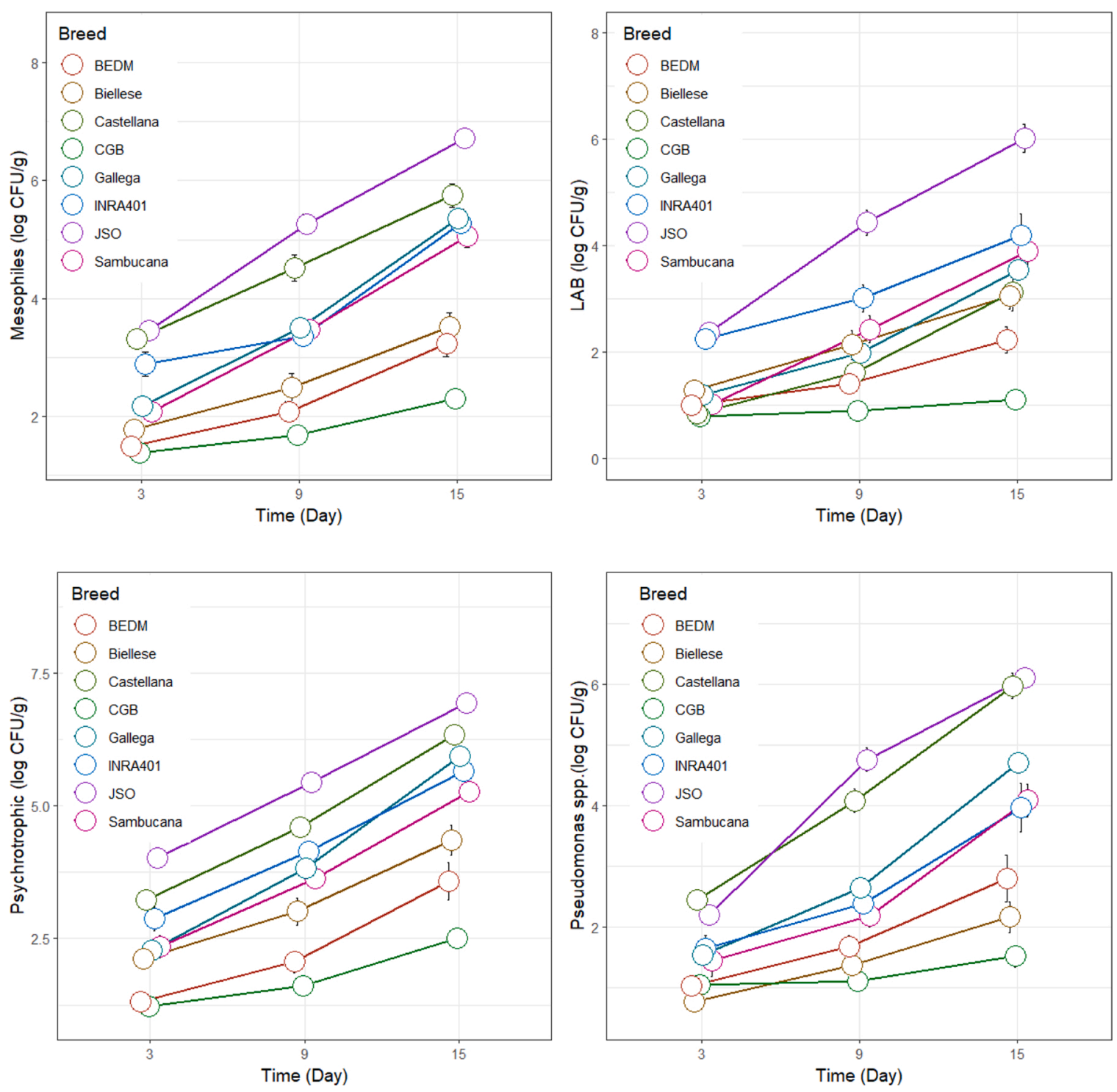

Fig. 1. Increase in microbial populations in vacuum-packed lamb meat stored at $4{ }^{\circ} \mathrm{C}$ during 15 days, by local breed: Bordaleira-Entre-Douro-e-Minho (BEDM), Biellese, Castellana, Churra-Galega-Bragançana (CGB), Gallega, INRA401, JSO (Jezersko-Solčava) and Sambucana. 
explained that, after vacuum-packaging, the population of LAB is generally low $\left(10 \mathrm{LAB} / \mathrm{cm}^{2}\right)$ but it increases during storage until growth stops due to substrate depletion. At $-1.5^{\circ} \mathrm{C}$, growing $\mathrm{LAB}$ populations in VP beef have been shown to be displaced by succeeding populations without a decline in observable LAB numbers (Jones, 2004).

It can be appreciated in Fig. 1 that, for the four bacterial groups, the differences in microbial numbers among lamb breeds further spread out as storage time elapsed. While deteriorating bacteria increased as maturation took place ( $\mathrm{p}<0.0001$ for the terms Day and Day ${ }^{2}$ in Tables 1 and 2), the microbial growth trends were clearly different between breeds (Fig. 1). Furthermore, the order of the breeds given by the size of the bacterial population was recurrent in the four bacterial groups analysed. Fig. 2 shows an illustration of such differences (and similarities) by plotting the random effects of the model's intercept $\left(u_{0 r}\right.$, which represent shifts in the mean initial contamination load) and the random effects of the model's time slope $\left(u_{1 r}\right.$, which represent shifts in the mean effect of storage time, directly related to the growth rate of the microorganisms). Since four bacterial groups were analysed, every farm is characterised by four points in the two-dimensional space. First of all, the scatter plot revealed a direct association between the two random effects, $u_{0 r}$ and $u_{1 r}$, which signifies that meat with a high initial bacterial load tends to have a greater rate of deterioration (greater effect of time). On the contrary, low populations of spoilage bacteria initially present in lamb meat will translate into longer shelf life. The direct relationship between initial bacterial load and growth rate was not unexpected since this is linked to microbial growth theory, whereby microbial specific growth rate changes in time and is proportional to the microbial population size.

Secondly, the four types of spoilage indicators were highly clustered within sheep farm - except for the Castellana breed in semi-extensive production - which means that the counts of mesophiles, LAB, psychrotrophic bacteria and Pseudomonas tend to be correlated. That is, under vacuum conditions, the higher the concentration of one bacterial group, the higher the concentrations of the three other groups. This was an expected association since all of these spoilage indicators develop simultaneously. Thirdly, since the higher the random effects, the greater the initial bacterial load and their growth in time, it can be inferred from the scatter plot that lamb meat from the farms INRA401 intensive, Castellana semi-extensive, Castellana intensive and JSO extensive harboured the highest numbers of spoilage bacteria, whereas the lamb meat from the farms BEDM extensive and CGB semi-extensive the lowest. Lamb meat from Biellese semi-extensive, Gallega semi-extensive and extensive, and Sambucana extensive presented intermediate levels of deteriorating bacteria (Fig. 2). Nonetheless, despite the farm-to-farm variability in the numbers of spoilage microorganisms quantified in lamb meat, during the 15-day cold storage period, the beginning of microbial spoilage was not reached in any of the samples. Spoilage of raw meat is detected when mesophiles reach between $\sim 7 \mathrm{log} \mathrm{CFU} / \mathrm{g}$ (off-odour) and $8 \log \mathrm{CFU} / \mathrm{g}$ (slime), and psychrotrophic bacteria reach $\sim 8 \log \mathrm{CFU} / \mathrm{g}$ (Prieto et al., 1991). The current study found mean maximum populations of mesophiles at $6.72 \mathrm{log} \mathrm{CFU} / \mathrm{g}$ and psychrotrophic bacteria at $6.93 \mathrm{log} \mathrm{CFU} / \mathrm{g}$ on the 15th day of storage (Fig. 1), in all cases below the spoilage thresholds referred above.

Pre- and post-slaughter factors may have played a role in the observed farm-to-farm differences in the levels and rate of microbiological deterioration of lamb meat. Animals subjected to pre-slaughter stress during transportation and/or lairaige produce meat of higher $\mathrm{pH}(>5.70)$ that translates into better conditions for microbial growth. Furthermore, immediately after slaughtering, when the muscle tissue is exposed, it may be contaminated by deteriorative bacteria from the hide's normal microbiota (staphylococci, micrococci, pseudomonads, molds and yeasts) as well as from faecal origin bacteria (Martineli et al., 2009). Hooves, hide, hair, fleece and guts are considered the most important sources of microbial contamination on flayed carcasses (Bell and Hathway, 1996), but there are potential sources of contamination such as equipments, utensils and operators (Sierra et al., 1995). For

Table 1

Effects of lamb breed and initial intrinsic factors of meat on the concentration of mesophilic and lactic acid bacteria in refrigerated vacuum-packed meat as quantified by seven separate linear mixed models (F-values and associated p-values from ANOVA are shown).

\begin{tabular}{|c|c|c|c|c|c|}
\hline \multirow{2}{*}{ Model } & \multirow{2}{*}{ Term } & \multicolumn{2}{|l|}{ Mesophiles } & \multicolumn{2}{|c|}{ Lactic acid bacteria } \\
\hline & & Estimate (SE) & F (p-value) & Estimate (SE) & F (p-value) \\
\hline Cold & Intercept & $1.694(0.275)$ & $5.465(0.020)$ & $0.734(0.177)$ & $4.312(0.038)$ \\
\hline carcass & Day & $1.210(0.266)$ & $45.36(<.0001)$ & $0.803(0.295)$ & $33.35(<.0001)$ \\
\hline weight & Day $^{2}$ & $0.182(0.045)$ & $16.61(<0001)$ & $0.196(0.050)$ & $15.56(0.001)$ \\
\hline$(\mathrm{kg})$ & CCW $\times$ Day & $-0.052(0.006)$ & $69.42(<.0001)$ & $-0.033(0.007)$ & $22.29(<.0001)$ \\
\hline \multirow[t]{4}{*}{$\mathrm{pH}_{24}$ * } & Intercept & $13.77(1.818)$ & $829.5(<.0001)$ & $6.019(1.526)$ & $170.5(<.0001)$ \\
\hline & Day & $-0.586(0.244)$ & $23.86(<.0001)$ & $-0.466(0.258)$ & $17.80(<.0001)$ \\
\hline & Day $^{2}$ & $0.005(0.001)$ & $10.61(0.001)$ & $0.007(0.001)$ & $24.62(<.0001)$ \\
\hline & $\mathrm{pH} \times$ Day & $0.125(0.042)$ & $8.775(0.003)$ & $0.092(0.045)$ & $4.210(0.040)$ \\
\hline \multirow[t]{4}{*}{$a_{w}{ }^{*}$} & Intercept & $1.844(0.352)$ & $10.73(0.001)$ & $1.175(0.428)$ & $31.79(<.0001)$ \\
\hline & Day & $7.200(11.51)$ & $30.46(<.0001)$ & $8.460(4.029)$ & $47.97(<.0001)$ \\
\hline & Day $^{2}$ & $0.230(0.049)$ & $22.19(<.0001)$ & $0.294(0.072)$ & $16.65(<.0001)$ \\
\hline & aw $\times$ Day & $-7.109(11.6)$ & $0.375(0.540)$ & $-8.550(8.081)$ & $0.360(0.620)$ \\
\hline \multirow{4}{*}{ Moisture (\%) } & Intercept & $1.691(0.279)$ & $8.006(0.005)$ & $0.734(0.182)$ & $4.314(0.038)$ \\
\hline & Day & $-6.26(1.401)$ & $48.13(<.0001)$ & -3.533 (1.509) & $33.78(<.0001)$ \\
\hline & Day $^{2}$ & $0.187(0.047)$ & $15.05(0.001)$ & $0.197(0.051)$ & $14.75(0.001)$ \\
\hline & Moisture $\times$ Day & $0.088(0.018)$ & $23.64(<.0001)$ & $0.048(0.019)$ & $6.121(0.014)$ \\
\hline \multirow{4}{*}{ Fat $(\% \mathrm{db})$} & Intercept & $1.691(0.279)$ & $9.485(0.002)$ & $0.743(0.182)$ & $4.245(0.040)$ \\
\hline & Day & $0.582(0.252)$ & $54.34(<.0001)$ & $0.462(0.285)$ & $33.09(<.0001)$ \\
\hline & Day $^{2}$ & $0.183(0.048)$ & $14.66(0.001)$ & $0.197(0.051)$ & $14.84(0.001)$ \\
\hline & Fat $\times$ Day & $-0.019(0.006)$ & $9.107(0.003)$ & $-0.019(0.007)$ & $8.040(0.005)$ \\
\hline \multirow{4}{*}{ Protein (\% db) } & Intercept & $1.541(0.436)$ & $79.14(<.0001)$ & $0.734(0.182)$ & $4.282(0.039)$ \\
\hline & Day & $-1.604(0.489)$ & $1350(<.0001)$ & $-0.843(0.655)$ & $33.50(<.0001)$ \\
\hline & Day $^{2}$ & $0.183(0.058)$ & $9.803(0.002)$ & $0.197(0.051)$ & $14.72(0.001)$ \\
\hline & Protein $\times$ Day & $0.013(0.005)$ & $6.548(0.011)$ & $0.014(0.007)$ & $3.829(0.050)$ \\
\hline \multirow{4}{*}{ Ashes (\% db) } & Intercept & $1.589(0.187)$ & $10.95<.0001)$ & $0.734(0.182)$ & $4.099(0.043)$ \\
\hline & Day & $0.004(0.364)$ & $58.57(<.0001)$ & $-0.737(0.363)$ & $31.71(<.0001)$ \\
\hline & Day $^{2}$ & $0.183(0.053)$ & $14.23(0.001)$ & $0.197(0.051)$ & $14.83(<.0001)$ \\
\hline & Ashes $\times$ Day & $0.095(0.044)$ & $3.476(0.031)$ & $0.215(0.046)$ & $21.71(<.0001)$ \\
\hline
\end{tabular}

* Lamb meat from Slovenian breed not included since $\mathrm{pH}_{24}$ and $\mathrm{a}_{\mathrm{w}}$ was not measured in these samples. 
Table 2

Effects of lamb breed and initial intrinsic factors of meat on the concentration of Pseudomonas spp. and psychrotrophic bacteria in refrigerated vacuumpacked meat as quantified by seven separate linear mixed models (F-values and associated p-values from ANOVA are shown).

\begin{tabular}{|c|c|c|c|c|c|}
\hline \multirow[b]{2}{*}{ Model } & \multirow[b]{2}{*}{ Term } & \multicolumn{2}{|c|}{ Pseudomonas spp. } & \multicolumn{2}{|c|}{ Psychrotrophic bacteria } \\
\hline & & $\begin{array}{l}\text { Estimate } \\
\text { (SE) }\end{array}$ & F (p-value) & $\begin{array}{l}\text { Estimate } \\
\text { (SE) }\end{array}$ & $\mathrm{F}$ (p-value) \\
\hline Cold & Intercept & $\begin{array}{l}1.135 \\
(0.216)\end{array}$ & $\begin{array}{l}5.191 \\
(0.023)\end{array}$ & $\begin{array}{l}1.780 \\
(0.326)\end{array}$ & $\begin{array}{l}0.001 \\
(0.989)\end{array}$ \\
\hline carcass & Day & $\begin{array}{l}0.696 \\
(0.321)\end{array}$ & $\begin{array}{l}29.04 \\
(<.0001)\end{array}$ & $\begin{array}{l}1.201 \\
(0.272)\end{array}$ & $\begin{array}{l}66.04 \\
(<.0001)\end{array}$ \\
\hline weight & Day $^{2}$ & $\begin{array}{l}0.267 \\
(0.052)\end{array}$ & $\begin{array}{l}26.92 \\
(<.0001)\end{array}$ & $\begin{array}{l}0.229 \\
(0.049)\end{array}$ & $\begin{array}{l}21.42 \\
(<.0001)\end{array}$ \\
\hline$(\mathrm{kg})$ & $\begin{array}{l}\text { CCW } \times \\
\text { Day }\end{array}$ & $\begin{array}{l}-0.038 \\
(0.007)\end{array}$ & $\begin{array}{l}28.45 \\
(<.0001)\end{array}$ & $\begin{array}{l}-0.053 \\
(0.006)\end{array}$ & $\begin{array}{l}75.60 \\
(<.0001)\end{array}$ \\
\hline \multirow[t]{4}{*}{$\mathrm{pH}_{24} *$} & Intercept & $\begin{array}{l}8.739 \\
(1.601)\end{array}$ & $\begin{array}{l}313.2 \\
(<.0001)\end{array}$ & $\begin{array}{l}17.31 \\
(1.902)\end{array}$ & $\begin{array}{l}684.2 \\
(<.0001)\end{array}$ \\
\hline & Day & $\begin{array}{l}-0.460 \\
(0.263)\end{array}$ & $\begin{array}{l}26.40 \\
(<.0001)\end{array}$ & $\begin{array}{l}-0.945 \\
(0.245)\end{array}$ & $\begin{array}{l}32.91 \\
(<.0001)\end{array}$ \\
\hline & Day $^{2}$ & $\begin{array}{l}0.007 \\
(0.001)\end{array}$ & $\begin{array}{l}20.74 \\
(<.0001)\end{array}$ & $\begin{array}{l}0.006 \\
(0.002)\end{array}$ & $\begin{array}{l}13.59 \\
(<.0001)\end{array}$ \\
\hline & $\mathrm{pH} \times$ Day & $\begin{array}{l}0.104 \\
(0.045)\end{array}$ & $\begin{array}{l}5.151 \\
(0.024)\end{array}$ & $\begin{array}{l}0.192 \\
(0.042)\end{array}$ & $\begin{array}{l}20.52 \\
(<.0001)\end{array}$ \\
\hline \multirow[t]{4}{*}{$a_{w}^{*}$} & Intercept & $\begin{array}{l}1.466 \\
(0.573)\end{array}$ & $\begin{array}{l}36.49 \\
(<.0001)\end{array}$ & $\begin{array}{l}1.625 \\
(0.359)\end{array}$ & $\begin{array}{l}0.948 \\
(0.331)\end{array}$ \\
\hline & Day & $\begin{array}{l}13.22 \\
(9.349)\end{array}$ & $\begin{array}{l}785 \\
(<.0001)\end{array}$ & $\begin{array}{l}1.467 \\
(9.866)\end{array}$ & $\begin{array}{l}40.73 \\
(<.0001)\end{array}$ \\
\hline & Day $^{2}$ & $\begin{array}{l}0.317 \\
(0.080)\end{array}$ & $\begin{array}{l}15.67 \\
(0.001)\end{array}$ & $\begin{array}{l}0.254 \\
(0.055)\end{array}$ & $\begin{array}{l}21.74 \\
(<.0001)\end{array}$ \\
\hline & aw $\times$ Day & $\begin{array}{l}-13.29 \\
(9.413)\end{array}$ & $\begin{array}{l}1.993 \\
(0.159)\end{array}$ & $\begin{array}{l}-1.178 \\
(9.942)\end{array}$ & $\begin{array}{l}0.014 \\
(0.906)\end{array}$ \\
\hline \multirow{5}{*}{$\begin{array}{l}\text { Moisture } \\
(\%)\end{array}$} & Intercept & $\begin{array}{l}1.134 \\
(0.217)\end{array}$ & $\begin{array}{l}5.589 \\
(0.018)\end{array}$ & $\begin{array}{l}1.619 \\
(0.205)\end{array}$ & $\begin{array}{l}166.1 \\
(<.0001)\end{array}$ \\
\hline & Day & $\begin{array}{l}-6.429 \\
(1.556)\end{array}$ & $\begin{array}{l}26.52 \\
(<.0001)\end{array}$ & $\begin{array}{l}-5.769 \\
(1.357)\end{array}$ & $\begin{array}{l}38.05 \\
(<.0001)\end{array}$ \\
\hline & Day $^{2}$ & $\begin{array}{l}0.267 \\
(0.052)\end{array}$ & $\begin{array}{l}26.24 \\
(<.0001)\end{array}$ & $\begin{array}{l}0.229 \\
(0.057)\end{array}$ & $\begin{array}{l}15.85 \\
(<.0001)\end{array}$ \\
\hline & $\begin{array}{l}\text { Moisture } \\
\times \text { Day }\end{array}$ & $\begin{array}{l}0.086 \\
(0.020)\end{array}$ & $\begin{array}{l}18.51 \\
(<.0001)\end{array}$ & $\begin{array}{l}0.082 \\
(0.017)\end{array}$ & $\begin{array}{l}22.46 \\
(<.0001)\end{array}$ \\
\hline & Intercept & $\begin{array}{l}1.134 \\
(0.218)\end{array}$ & $\begin{array}{l}6.936 \\
(0.009)\end{array}$ & $\begin{array}{l}1.619 \\
(0.206)\end{array}$ & $\begin{array}{l}167.4 \\
(<.0001)\end{array}$ \\
\hline \multirow{4}{*}{ Fat $(\% \mathrm{db})$} & Day & $\begin{array}{l}0.275 \\
(0.309)\end{array}$ & $\begin{array}{l}29.59 \\
(<.0001)\end{array}$ & $\begin{array}{l}0.606 \\
(0.318)\end{array}$ & $\begin{array}{l}42.43 \\
(<.0001)\end{array}$ \\
\hline & Day $^{2}$ & $\begin{array}{l}0.267 \\
(0.052)\end{array}$ & $\begin{array}{l}25.79 \\
(<.0001)\end{array}$ & $\begin{array}{l}0.229 \\
(0.058)\end{array}$ & $\begin{array}{l}15.64 \\
(<.0001)\end{array}$ \\
\hline & Fat $\times$ Day & $\begin{array}{l}-0.019 \\
(0.007)\end{array}$ & $\begin{array}{l}7.270 \\
(0.007)\end{array}$ & $\begin{array}{l}-0.017 \\
(0.006)\end{array}$ & $\begin{array}{l}7.503 \\
(0.006)\end{array}$ \\
\hline & Intercept & $\begin{array}{l}1.135 \\
(0.219)\end{array}$ & $\begin{array}{l}7.041 \\
(0.008)\end{array}$ & $\begin{array}{l}6.953 \\
(1.237)\end{array}$ & $\begin{array}{l}723.1 \\
(<.0001)\end{array}$ \\
\hline \multirow{3}{*}{$\begin{array}{l}\text { Protein (\% } \\
\quad \text { db) }\end{array}$} & Day & $\begin{array}{l}-1.002 \\
(0.643)\end{array}$ & $\begin{array}{l}30.38 \\
(<.0001)\end{array}$ & $\begin{array}{l}-0.339 \\
(0.151)\end{array}$ & $\begin{array}{l}44.77 \\
(<.0001)\end{array}$ \\
\hline & Day $^{2}$ & $\begin{array}{l}0.267 \\
(0.053)\end{array}$ & $\begin{array}{l}25.64 \\
(<.0001)\end{array}$ & $\begin{array}{l}0.006 \\
(0.002)\end{array}$ & $\begin{array}{l}13.56 \\
(0.001)\end{array}$ \\
\hline & $\begin{array}{l}\text { Protein } \times \\
\text { Day }\end{array}$ & $\begin{array}{l}0.013 \\
(0.007)\end{array}$ & $\begin{array}{l}3.985 \\
(0.046)\end{array}$ & $\begin{array}{l}0.006 \\
(0.002)\end{array}$ & $\begin{array}{l}10.99 \\
(0.001)\end{array}$ \\
\hline \multirow{4}{*}{$\begin{array}{c}\text { Ashes (\% } \\
\text { db) }\end{array}$} & Intercept & $\begin{array}{l}0.972 \\
(0.481)\end{array}$ & $\begin{array}{l}41.67 \\
(<.0001)\end{array}$ & $\begin{array}{l}1.620 \\
(0.206)\end{array}$ & $\begin{array}{l}167.3 \\
(<.0001)\end{array}$ \\
\hline & Day & $\begin{array}{l}0.417 \\
(0.350)\end{array}$ & $\begin{array}{l}976 \\
(<.0001)\end{array}$ & $\begin{array}{l}-0.045 \\
(0.372)\end{array}$ & $\begin{array}{l}44.02 \\
(<.0001)\end{array}$ \\
\hline & Day $^{2}$ & $\begin{array}{l}0.266 \\
(0.070)\end{array}$ & $\begin{array}{l}14.04 \\
(<.0001)\end{array}$ & $\begin{array}{l}0.229 \\
(0.058)\end{array}$ & $\begin{array}{l}15.51 \\
(<.0001)\end{array}$ \\
\hline & $\begin{array}{l}\text { Ashes } \times \\
\text { Day }\end{array}$ & $\begin{array}{l}-0.040 \\
(0.01)\end{array}$ & $\begin{array}{l}0.993 \\
(0.319)\end{array}$ & $\begin{array}{l}0.105 \\
(0.040)\end{array}$ & $\begin{array}{l}6.751 \\
(0.010)\end{array}$ \\
\hline
\end{tabular}

* Lamb meat from Slovenian breed not included since $\mathrm{pH}_{24}$ and $\mathrm{a}_{\mathrm{w}}$ was not measured in these samples.

instance, Drosinos and Board (1995) isolated Pseudomonas fragi, $P$. fluorescens and $P$. lundensis from boning tables, mixing equipment, conveyor belts and trays from a lamb processing plant. They explained that the incidence of fluorescent pseudomonads in meat factories and their association with free water on surface may account for their ocassionally high occurrence in lamb meat. In addition, the oxygen concentration, undissociated lactic acid concentration and $\mathrm{pH}$ of lamb meat are selective determinants of the dominant microflora and its

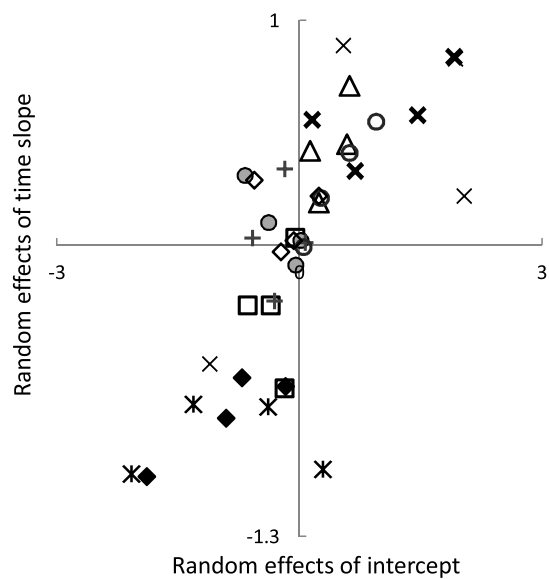

- BEDM Extensive

$\square$ Biellese Semi-extensive

$\Delta$ Castellana Intensive

$\times$ Castellana Semi-extensive

X CGB Semi-extensive

O Gallega Extensive

+ Gallega Semi-extensive

O INRA401 Intensive

XJSO Extensive

๑Sambucana Extensive

Random effects of intercept

Fig. 2. Scatter plot of the random effects due to sheep farm for intercept $\left(u_{0 r}\right)$ and time slope $\left(\mathrm{u}_{1 \mathrm{r}}\right)$, estimated from the mixed-effects models for the four bacterial groups.

succession.

In an attempt to explain the between-farm variability in the numbers of spoilage bacteria in lamb meat, the initial intrinsic factors of meat were recorded. Although all lamb animals were slaughtered at the age of 4-5 months, significant differences were found for CCW of lambs between farms. Differences in CCW were highly linked to the production system. CCW of intensively-raised lambs (21.4 kg; 95 \% CI: 20.6-22.1 $\mathrm{kg}$ ) were higher $(\mathrm{p}<0.05)$ than the ones in semi-extensive regime $(14.9$ kg; $95 \%$ CI: $14.4-15.4 \mathrm{~kg}$ ), and in turn these were heavier ( $<<0.05)$ than the extensively raised lambs (12.4 kg; $95 \%$ CI: 12.0-12.7). The heaviest carcasses were produced in intensive regime by Castellana farm (21.5 kg; 95 \% CI: 20.9-22.0 kg) and INRA401 farm (21.2 kg; $95 \%$ CI: 20.4-22.0 kg), followed by the medium-sized Biellese semi-extensive (16.8 kg; 95 \% CI: 16.2-17.4 kg), Sambucana extensive (16.4 kg; 95 \% CI: 15.9-17.0 kg), Castellana semi-extensive (15.5 kg; $95 \%$ CI: 14.7-16.3 kg) and CGB semi-extensive (14.3 kg; $95 \%$ CI: 13.7-14.8 kg). The smallest carcasses were mostly produced in extensive regime by Gallega farm (12.5 kg; $95 \%$ CI: 12.1-12.9 kg), JSO farm (12.6 kg; $95 \%$ CI: $12.0-13.3 \mathrm{~kg})$, BEDM farm $(7.03 \mathrm{~kg} ; 95 \% \mathrm{CI}: 6.45-7.60 \mathrm{~kg})$ and Gallega semi-extensive farm (11.4 kg; $95 \%$ CI: 10.5-12.2 kg) (Table 3).

In the mixed-effects models (Tables 1 and 2), the negative estimates for the interaction CCW $\times$ Day imply that meat from heavier carcasses supported a slower microbial growth $(\mathrm{p}<.0001$ for the four bacterial groups). Thus, the rate of meat spoilage is regulated by CCW, probably because of the greater amount of intramuscular fat present in this meat. Lambs in extensive production systems tended to produce meat of higher ( $\mathrm{p}<0.05$ ) $\mathrm{pH}_{24}$ (5.679; 95 \% CI: 5.657-5.702) than those from both semi-intensive (5.596; $95 \%$ CI: 5.562-5.629) and intensive regimes (5.600; $95 \%$ CI: 5.562-5.638). The effect of $\mathrm{pH}_{24}$ on the steeper or slower microbial growth can be also deduced from the interaction term $\mathrm{pH}_{24} \times$ Day, which turned out to be significant for the four bacterial groups, namely mesophiles ( $p=0.003$ in Table 1 ), LAB ( $p=0.040$ in Table 1), Pseudomonas ( $\mathrm{p}=0.024$ in Table 2 ) and psychrotrophic bacteria ( $\mathrm{p}<0.0001$ in Table 2). The positive estimates for the interaction $\mathrm{pH} \times$ Day suggest that, within farms, a higher ultimate $\mathrm{pH}$ of meat tends to accelerate the microbial growth, thereby reducing shelf life.

Meat $\mathrm{pH}$ has been shown to affect the growth of bacteria in two ways (Gill, 2004). Firstly, the growth of some bacteria is reduced, or inhibited completely, when the $\mathrm{pH}$ falls below a certain level. Secondly, the glycolytic processes that determine the ultimate $\mathrm{pH}$ also determine the concentration of residual glucose in the meat, and therefore the point at which this preferred growth substrate becomes exhausted and amino acids start to be metabolised by LAB and Enterobacteriaceae, thereby resulting in spoilage. For instance, it is generally accepted that Enterobacteriaceae and Brochothrix thermosphacta are inhibited by $\mathrm{pH}$ values 
Table 3

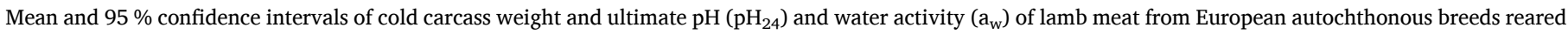
under extensive (Ext), intensive (Int) or semi-extensive (Semi-ext) production systems.

\begin{tabular}{|c|c|c|c|}
\hline Breed - Production & Cold carcass weight $[\mathrm{kg}]$ & $\mathrm{pH}_{24}$ & $\mathrm{a}_{\mathrm{w}}$ \\
\hline \multicolumn{4}{|l|}{ Portugal } \\
\hline \multirow[t]{2}{*}{$\mathrm{BEDM}^{*}-$ Ext } & $7.03^{\mathrm{a}}$ & $5.798^{\mathrm{f}}$ & $0.9927^{c}$ \\
\hline & {$[6.45-7.60]$} & [5.769-5.828] & {$[0.9922-0.9932]$} \\
\hline \multirow[t]{2}{*}{ CGB $^{*}-$ Semi-ext } & $14.3^{\mathrm{c}}$ & $5.614^{c}$ & $0.9927^{\mathrm{c}}$ \\
\hline & [13.7-14.8] & [5.586-5.641] & {$[0.9923-0.9932]$} \\
\hline \multicolumn{4}{|l|}{ Spain } \\
\hline \multirow[t]{2}{*}{ Castellana - Int } & $21.5^{\mathrm{e}}$ & $5.548^{\mathrm{bc}}$ & $0.9912^{\mathrm{b}}$ \\
\hline & [20.9-22.0] & [5.520-5.576] & [0.9908 - 0.9917] \\
\hline \multirow[t]{2}{*}{ Castellana - Semi-ext } & $15.5^{\mathrm{cd}}$ & $5.539^{\mathrm{b}}$ & $0.9914^{\mathrm{b}}$ \\
\hline & [14.7-16.3] & {$[5.500-5.578]$} & {$[0.9907-0.9921]$} \\
\hline \multirow[t]{2}{*}{ Gallega - Ext } & $12.5^{\mathrm{b}}$ & $5.730^{\mathrm{e}}$ & $0.9937^{\mathrm{d}}$ \\
\hline & [12.1-12.9] & [5.712-5.747] & {$[0.9934-0.9940]$} \\
\hline \multirow[t]{2}{*}{ Gallega - Semi-ext } & $11.4^{\mathrm{b}}$ & $5.622^{\text {bcd }}$ & $0.9939^{\mathrm{d}}$ \\
\hline & [10.5-12.2] & [5.579-5.666] & [0.9931 - 0.9946] \\
\hline \multirow[t]{2}{*}{ INRA401 - Int } & $21.2^{\mathrm{e}}$ & $5.712^{\mathrm{de}}$ & $0.9888^{\mathrm{a}}$ \\
\hline & [20.4-22.0] & {$[5.672-5.753]$} & {$[0.9881-0.9895]$} \\
\hline \multicolumn{4}{|l|}{ Italy } \\
\hline \multirow[t]{2}{*}{ Biellese - Semi-ext } & $16.8^{\mathrm{d}}$ & $5.621^{\mathrm{bcd}}$ & $\mathrm{ND}^{* *}$ \\
\hline & {$[16.2-17.4]$} & [5.507-5.735] & \\
\hline \multirow[t]{2}{*}{ Sambucana - Ext } & $16.4^{\mathrm{d}}$ & $5.689^{\text {cde }}$ & ND \\
\hline & [15.9-17.0] & [5.608-5.769] & \\
\hline \multicolumn{4}{|l|}{ Slovenia } \\
\hline \multirow[t]{2}{*}{ JSO ${ }^{*}$ - Ext } & $12.6^{\mathrm{b}}$ & $5.358^{\mathrm{a}}$ & ND \\
\hline & [12.0-13.3] & [5.325-5.390] & \\
\hline
\end{tabular}

a,b,c,d,e Different superscript letters in the same column indicate significant differences $(\mathrm{p}<0.05)$.

* CGB: Churra Galega Bragançana; BEDM: Bordaleira Entre Douro e Minho; JSO: Jezersko-Solčavska.

** Not determined.

lower than 5.8 (Bell, 2001). Grau (1980) found that undissociated lactic acid was a selective determinant on the growth of $B$. thermosphacta and its growth was inhibited at $\mathrm{pH}<5.7$ under anaerobic conditions. It could be postulated that in the interior of the commodity, where anaerobic conditions may exist, the high $\mathrm{pH}$ of the meat does not restrict the growth of this bacterium.

Differences in the mean ultimate $\mathrm{pH}$ of lamb meat were evident between farms (Table 3). Higher $\mathrm{pH}_{24}$ values were measured in lamb meat from BEDM extensive (5.798; 95 \% CI: 5.769-5.828), Gallega extensive (5.730; $95 \%$ CI: 5.712-5.747) and INRA401 intensive (5.712; $95 \%$ CI: 5.672-5.747) than in meat samples from Biellese semiextensive (5.689; $95 \%$ CI: 5.608-5.769), Gallega semi-extensive (5.622; 95 \% CI: 5.579-5.666), CGB semi-extensive (5.614; 95 \% CI: 5.586-5.641), Castellana intensive (5.548; $95 \%$ CI: 5.520-5.576) and semi-extensive (5.539; $95 \%$ CI: 5.500-5.578) and JSO extensive (5.358; 95 \% CI: 5.358-5.390). Although, as a whole, lamb meat has a higher mean ultimate $\mathrm{pH}(5.6-5.8)$ than beef meat $(\mathrm{pH}=5.5)$ (Drosinos and Board, 1995), our results still suggest that lambs from some farms may have been more susceptible to pre-mortem stress than others. Pre-slaughter stress of animals, occurring between 12-48 hours prior to slaughter, can be caused by fighting, cold weather, fasting and transit. The rapid depletion of glycogen levels, prompted by stress, prevents the normal drop in $\mathrm{pH}$ to optimal levels. As a result, meat of higher $\mathrm{pH}$ ( $>5.7$ ) has better conditions for microbial growth - as previously explained - ending up ultimately (and unavoidably) in a reduction of shelf-life in refrigerated conditions even when vacuum-packaging is applied.

In relation to meat $a_{w}$, its value was highly dependent on the production system ( $p<0.0001)$. Lamb meat samples from extensive systems presented higher $\mathrm{a}_{\mathrm{w}}(0.9934 ; 95 \%$ CI: $0.9931-0.9937)$ than those of semi-extensive systems (0.9926; $95 \%$ CI: $0.9922-0.9931)$, which in turn were higher than the lamb meat from the intensive systems (0.9905; 95 \% CI: $0.9899-0.9910)$. This intrinsic property was not found to modulate the growth of any microbial group, as deduced by the non-significance of the interaction term $\mathrm{a}_{\mathrm{w}} \times$ Day ( $\mathrm{p}=0.540$ for mesophiles; $\mathrm{p}=0.620$ for LAB; $\mathrm{p}=0.159$ for Pseudomonas; and $\mathrm{p}=0.906$ for psychrotrophic bacteria in Tables 1 and 2). The lack of effect of $a_{w}$ is not surprising since vacuum packaging prevents drying at the meat surface, and moisture from within the meat allows the surface $a_{w}$ to equilibrate. Consequently, there is no inhibitory effect on bacteria once the meat has been packed and stored (Bell, 2001). In addition, there was not high variability in $\mathrm{a}_{\mathrm{w}}$ measured on the third day after slaughter. Except for the VP lamb meat from INRA401 intensive farm, which presented the lowest mean $\mathrm{a}_{\mathrm{w}}$ (0.9888), the VP lamb meat from Portuguese and Spanish farms present mean $\mathrm{a}_{\mathrm{w}}$ values between 0.9912 and 0.9939

Table 4

Mean and $95 \%$ confidence intervals of the proximate composition of lamb meat from European autochthonous breeds reared under extensive (Ext), intensive (Int) or semi-extensive (Semi-ext) production systems.

\begin{tabular}{ccccc}
\hline Breed - & Moisture $(\mathrm{g} /$ & $\begin{array}{c}\text { Protein }(\mathrm{g} / \\
100 \mathrm{~g} \mathrm{db})\end{array}$ & $\begin{array}{c}\text { Fat }(\mathrm{g} / 100 \mathrm{~g} \\
\mathrm{db})\end{array}$ & $\begin{array}{c}\text { Ashes }(\mathrm{g} / 100 \\
\mathrm{g} \mathrm{db})\end{array}$ \\
\hline Production & $100 \mathrm{~g})$ & & & \\
Portugal & & & & \\
BEDM $^{*}-$ Ext & $77.0^{\mathrm{e}}$ & $87.4^{\mathrm{e}}$ & $3.78^{\mathrm{a}}$ & $5.65^{\mathrm{e}}$ \\
& {$[76.8-77.3]$} & {$[86.6-88.2]$} & {$[3.06-4.50]$} & {$[5.54-5.76]$} \\
CGB $^{*}-$ Int & $75.9^{\mathrm{d}}$ & $85.6^{\mathrm{bcd}}$ & $6.91^{\mathrm{b}}$ & $5.17^{\mathrm{d}}$ \\
& {$[75.6-76.1]$} & {$[84.8-86.3]$} & {$[6.21-7.61]$} & {$[5.06-5.27]$} \\
Spain & & & & \\
Castellana - & $74.8^{\mathrm{ab}}$ & $85.5^{\mathrm{bcd}}$ & $9.27^{\mathrm{d}}$ & $4.75^{\mathrm{ab}}$ \\
Int & {$[74.5-75.0]$} & {$[84.8-86.3]$} & {$[8.57-9.96]$} & {$[4.65-4.86]$} \\
Castellana - & $75.8^{\mathrm{cd}}$ & $84.5^{\mathrm{b}}$ & $7.38^{\mathrm{bcd}}$ & $4.82^{\mathrm{abc}}$ \\
Semi-ext & {$[75.5-76.1]$} & {$[83.5-85.6]$} & {$[6.39-8.36]$} & {$[4.67-4.96]$} \\
Gallega - Ext & $75.0^{\mathrm{b}}$ & $85.2^{\mathrm{bc}}$ & $8.65^{\mathrm{cd}}$ & $4.99^{\mathrm{cd}}$ \\
& {$[74.8-75.2]$} & {$[84.8-85.7]$} & {$[8.21-9.10]$} & {$[4.92-5.05]$} \\
Gallega - & $75.4^{\mathrm{bcd}}$ & $86.6^{\mathrm{cde}}$ & $6.87^{\mathrm{bc}}$ & $4.86^{\mathrm{abcd}}$ \\
Semi-ext & {$[75.0-75.8]$} & {$[85.4-87.7]$} & {$[5.77-7.97]$} & {$[4.70-5.03]$} \\
INRA401 - & $75.2^{\mathrm{bc}}$ & $85.3^{\mathrm{bcd}}$ & $7.16^{\mathrm{bc}}$ & $4.95^{\mathrm{bcd}}$ \\
Int & {$[74.8-75.5]$} & {$[84.2-86.4]$} & {$[6.14-8.18]$} & {$[4.80-5.11]$} \\
Italy & & & & \\
Biellese - & $77.3^{\mathrm{e}}$ & $86.6^{\mathrm{cde}}$ & $6.96^{\mathrm{b}}$ & $4.69^{\mathrm{ab}}$ \\
Semi-ext & {$[77.1-77.5]$} & {$[85.9-87.4]$} & {$[6.24-7.68]$} & {$[4.58-4.80]$} \\
Sambucana - & $77.2^{\mathrm{e}}$ & $87.2^{\mathrm{de}}$ & $6.06^{\mathrm{b}}$ & $4.75^{\mathrm{ab}}$ \\
Ext & {$[76.9-77.4]$} & {$[86.5-87.9]$} & {$[5.39-6.73]$} & {$[4.65-4.85]$} \\
Slovenia & & & & \\
JSO* - Ext & $74.3^{\mathrm{a}}$ & $76.5^{\mathrm{a}}$ & $13.1^{\mathrm{e}}$ & $4.62^{\mathrm{a}}$ \\
& {$[74.1-74.6]$} & {$[75.6-77.4]$} & {$[12.2-13.9]$} & {$[4.50-4.75]$} \\
\hline
\end{tabular}

* CGB: Churra Galega Bragançana; BEDM: Bordaleira Entre Douro e Minho; JSO: Jezersko-Solčavska. 
(Table 3). Although not measured in the present experiment, $\mathrm{a}_{\mathrm{w}}$ of vacuum-packed meat during cold storage is expected to drop until stabilisation above 0.98 (Bell, 2001).

Unlike $a_{w}$, the growth of spoilage bacteria was found to be exacerbated by the moisture content of meat, as implied by the interaction terms Moisture $\times$ Day that were significant in all bacterial groups $(\mathrm{p}=$ 0.014 for $\mathrm{LAB}$ and $\mathrm{p}<0.0001$ for the others in Tables 1 and 2). The positive sign of this interaction (ranging from 0.048 to 0.088 ) suggested that a higher moisture content in lamb meat before packaging prompted a faster increase in spoilage bacterial numbers in VP meat during cold storage. Meat samples may have had different levels of moisture, since lamb carcasses were held for $24 \mathrm{~h}$ in a chilling room at $\sim 90 \%$ relative humidity with loadings that varied from batch to batch. Under these conditions, moisture loss from lamb carcasses have been reported to be up to $2.2 \%$ (Brown et al., 1993). Thus, the mean moisture content of lamb meat originating from the different farms was variable (Table 4). Lamb meat of high mean moisture content (77.0-77.3\%) was obtained from BEDM extensive, Biellese semi-extensive and Sambucana extensive farms, whereas samples with low mean moisture content (74.3-75.0\%) originated from JSO extensive, Castellana intensive and Gallega extensive farms. Mean moisture contents in between (75.2-75.9\%) were measured in lamb meat from the INRA401 intensive, Gallega semi-extensive, Castellana semi-extensive and CGB intensive farms.

Interestingly, lamb meat samples of higher fat content underwent a slower microbial deterioration, as implied by the negative Fat $\times$ Day interaction (ranging between -0.019 to -0.017 ) that was significant for all microbial groups ( $\mathrm{p}=0.003$ for mesophiles, $\mathrm{p}=0.005$ for $\mathrm{LAB}, \mathrm{p}=$ 0.007 for Pseudomonas and $\mathrm{p}=0.006$ for psychrotrophic bacteria in Tables 1 and 2). The significant effect of meat fat content is linked to that of CCW, discussed earlier, since heavier carcasses produce meat of higher intramuscular fat. Fat has therefore an important role in delaying microbial spoilage, which could arise from two mechanisms. Fat cover has been demonstrated to protect carcasses against contamination and proliferation of bacteria. Sauter et al. (2006) found that lamb carcasses having $0.36 \mathrm{~cm}$ or less of fat cover presented significantly higher psychrotrophic counts on the surface; concluding that the population size of microorganisms up to 7 days post-slaughter was related to the thickness of fat cover. A second effect could be that the immobilisation of the bacteria by the lipid component causes a decreased rate of growth and a shrinkage of the habitat domain. This means that the conditions of $\mathrm{pH}$ and water activity that are required for the initiation of growth of immobilised bacteria are higher than for planktonic culture (Brocklehurst and Wilson, 2000).

Lamb meat originating from Sambucana extensive $(6.06 \% \mathrm{db})$, Gallega semi-extensive (6.87 \%), CGB - intensive (6.91\%), Biellese semi-extensive $(6.96 \%)$, INRA401 intensive $(7.16 \%)$ and Castellana semi-extensive $(7.38 \%)$ farms presented comparable levels of fat content; yet they were lower than the meat from Gallega extensive (8.65 \%), Castellana intensive $(9.27 \%)$ and JSO extensive $(13.1 \%)$. Animals from the BEDM farm produced meat with the lowest fat content $(3.78 \%)$ (Table 4). In general terms, the lamb meat from intensive (8.60\%; $95 \%$ CI: 7.77-9.42\% db) and semi-extensive (7.87 \%; $95 \%$ CI: 7.43-8.30\% $\mathrm{db})$ production systems presented higher fat content $(\mathrm{p}<0.05)$ than the meat produced by lambs in the extensive regime $(7.00 \%$; $95 \% \mathrm{CI}$ : $6.41-7.60 \% \mathrm{db})$.

The contents of crude protein and ashes in lamb meat also varied according to production system and sheep farm. Intensive (85.47\%; 95 $\%$ CI: 84.54-86.39\% db) and semi-extensive rearing systems (85.88\%; $95 \%$ CI: $85.21-86.54 \% \mathrm{db}$ ) produced meat of higher protein content than the extensive systems (84.79\%; $95 \%$ CI: 84.30-85.29\% db). By contrary, lamb meat from extensive systems had higher $(\mathrm{p}<0.05)$ ashes content (5.01\%; $95 \%$ CI: $4.94-5.07 \% \mathrm{db})$ than the meat produced in intensive systems ( $4.82 \%$; $95 \%$ CI: $4.70-4.93 \% \mathrm{db}$ ). Although the ash content of meat from lambs in semi-extensive system presented an intermediate mean value of $4.91 \%$ (95\% CI: 4.82-4.99\%), it did not differ statistically from the other two production systems.
The highest protein and ashes contents were quantified in lamb meat from the BEDM extensive farm $(87.4 \%$ and $5.65 \% \mathrm{db}$, respectively) and the lowest ones in meat samples from the JSO extensive farm $(76.5 \%$ and $4.62 \% \mathrm{db})$. Mean protein contents of meat from animals raised in Portugal (CGB breed) and Spain - except for BEDM breed and Gallega semi-extensive - were similar and within the range of $84.5-85.6 \% \mathrm{db}$. Higher mean protein contents were found in lamb meat from Gallega semi-extensive farm and the two Italian farms $(86.6-87.2 \% \mathrm{db})$. In terms of ash content, the lamb meat from the Italian farms, Castellana farms, and Gallega semi-extensive and INRA401 intensive farms were comparable with mean values between 4.69 and $4.95 \% \mathrm{db}$. Slightly higher mean ash contents were found in meat from the Gallega extensive $(4.99 \% \mathrm{db})$ and the CGB intensive farms $(5.17 \% \mathrm{db})$. Results from the mixed effects models suggested that, within farms, lamb meat samples of higher protein content would tend to have a faster microbial spoilage, as deduced from the positive interaction Protein $\times$ Day (values between 0.006 and 0.014) that were significant for the four bacterial groups $(\mathrm{p}=0.011$ for mesophiles, $\mathrm{p}=$ 0.050 for LAB, $\mathrm{p}=0.046$ for Pseudomonas and $\mathrm{p}=0.001$ for psychrotrophic bacteria). As Drosinos and Board (1995) point out, when carbohydrates and lactate are present in lamb meat, amino acids are used as building blocks and a source of nitrogen; yet, when glucose, glucose 6-phosphate and lactate have been catabolized, the aminoacids are utilised as carbon and energy sources. Likewise, meat with higher content of metals and minerals (i.e., ashes) supported a faster growth of mesophiles $(\mathrm{p}=0.031)$, LAB $(\mathrm{p}<0.0001)$ and psychrotrophic bacteria $(\mathrm{p}=0.010)$, although this could not be proven for Pseudomonas ( $\mathrm{p}=0.319$ ). As Gadd (2010) explains, metals such as $\mathrm{Na}, \mathrm{K}, \mathrm{Cu}$, $\mathrm{Zn}, \mathrm{Co}, \mathrm{Ca}, \mathrm{Mg}, \mathrm{Mn}$ and Fe are essential for life, and are directly and/or indirectly involved in all aspects of microbial growth, metabolism and differentiation. Furthermore, many important microbial processes can be influenced by minerals, including energy generation, nutrient acquisition, cell adhesion and biofilm formation.

This work has not only evidenced the significant differences in the microbiological quality of lamb meat from Spanish, Portuguese, Italian and Slovenian breeds, but has also revealed that there is still room for improvement in the management and quality systems adopted by lamb producers and processors. Since high carcass weight and intramuscular fat content are associated to slower spoilage process, within each breed producers should find an optimal slaughter age and level of fattening that ensures an appropriate fat cover on carcasses. Because ultimate $\mathrm{pH}$ also exerts a determinant role in the shelf life of meat, producers should avoid to subject lambs to pre-slaughter stress during transport and lairaige. In addition, as the performance of an implemented food safety management system at the processing level and the microbial safety levels of carcasses - and consequently meat - are interrelated, it is necessary for the small/ medium slaughterhouses that participated in this research to further control and improve hygiene and good manufacturing practices. Processors should be aware that slaughter operations such as dehiding and evisceration significantly affect the microbiological quality of the carcass, as well as other sources of contamination such as poorly sanitised equipment and non-trained operators.

\section{Conclusion}

Substantial variability in cold carcass weight was found between the ten farms from Portugal, Spain, Italy and Slovenia, with a clear trend evidencing that extensive regimes produce light carcasses $(12.4 \mathrm{~kg}$; $95 \%$ CI: $12.0-12.7)$ while intensive regimes heavy ones $(21.4 \mathrm{~kg}$; $95 \% \mathrm{CI}$ : 20.6-22.1 kg). Mean contents of protein, fat and ashes in lamb meat from the ten local breed farms were in the range of $76.5-87.4 \% \mathrm{db}$, $3.78-13.1 \% \mathrm{db}$ and $4.62-5.65 \% \mathrm{db}$, respectively; yet, they were affected by the type of production system. Although during the 15-day cold storage period, the populations of deteriorating microorganisms in vacuum-packed lamb meat were below the spoilage level, their numbers were highly variable between farms. Lamb meat from the farms 
INRA401, Castellana and JSO harboured the highest numbers of mesophiles, lactic acid bacteria, Pseudomonas and psychrotrophic bacteria, whereas the lamb meat from the farms BEDM and CGB presented the lowest numbers. Furthermore, the growth of spoilage bacteria was found to be exacerbated by higher ultimate $\mathrm{pH}$, higher moisture, higher protein and higher ash content. On the contrary, lamb meat from heavier carcasses, and therefore having a higher crude fat content, underwent a slower spoilage process. This study also revealed that some abattoirs need to enhance their slaughter and dressing procedures as well as their hygiene conditions to reduce the current microbial contamination levels of lamb meat. Furthermore, to further help extend the shelf-life of lamb meat, animal handling can be improved to minimise pre-slaughter stress, and a carcass classification system can be implemented towards the selection of fatter animals and chilled carcasses of optimal ultimate $\mathrm{pH}$.

\section{Declaration of Competing Interest}

The authors report no declarations of interest.

\section{CRediT authorship contribution statement}

Ursula Gonzales-Barron: Conceptualization, Formal analysis, Funding acquisition, Investigation, Methodology, Project administration, Resources, Software, Visualization, Writing - original draft, Writing - review \& editing. Sara Coelho-Fernandes: Investigation, Methodology, Visualization. Gisela Santos-Rodrigues: Investigation, Methodology, Visualization. Altino Choupina: Investigation, Methodology, Visualization. Roberto Bermúdez Piedra: Investigation, Methodology, Supervision, Validation, Visualization. Koldo Osoro: Funding acquisition, Project administration, Resources, Visualization, Writing - review \& editing. Rafael Celaya: Investigation, Methodology, Supervision, Validation, Visualization, Writing - review \& editing. Rocío R. García: Project administration, Visualization. Tanja Peric: Funding acquisition, Project administration, Resources, Visualization, Writing - review \& editing. Silvia Del Bianco: Investigation, Methodology, Supervision, Validation, Visualization. Edi Piasentier: Investigation, Methodology, Supervision, Validation, Visualization. Francesco Chiesa: Investigation, Methodology, Supervision, Validation, Visualization. Alberto Brugiapaglia: Investigation, Methodology, Supervision, Validation, Visualization. Luca Battaglini: Investigation, Methodology, Supervision, Validation, Visualization. Mario Baratta: Funding acquisition, Project administration, Resources, Visualization, Writing - review \& editing. Raúl Bodas: Funding acquisition, Project administration, Resources, Visualization, Writing - review \& editing. José M. Lorenzo: Conceptualization, Funding acquisition, Investigation, Methodology, Project administration, Resources, Supervision, Visualization, Writing review \& editing. Vasco A.P. Cadavez: Conceptualization, Formal analysis, Funding acquisition, Investigation, Methodology, Project administration, Resources, Software, Visualization, Writing - original draft, Writing - review \& editing.

\section{Acknowledgments}

The authors are grateful to EU ERA-NET programme and the Portuguese Foundation for Science and Technology (FCT) for funding the project "EcoLamb-Holistic Production to Reduce the Ecological Footprint of Meat (SusAn/0002/2016). CIMO authors are grateful to FCT and FEDER under Programme PT2020 for financial support to CIMO (UIDB/00690/2020). Dr. Gonzales-Barron acknowledges the national funding by FCT, P.I., through the Institutional Scientific Employment Programme contract. José M. Lorenzo is member of the HealthyMeat network, funded by CYTED (ref. 119RT0568). The authors would like to acknowledge also Elena Saccà and Angela Sepulcri for providing technical support in laboratory analyses.

\section{References}

Anonymous, 2000. Final report: an evaluation of the common organisation of the markets in the sheep and goat meat sector. Prepared for the Economic Analyses, Forward Studies and Evaluation Directorate of the European Commission Agriculture Directorate-general. SAC, Industry Strategy Consulting, INRA and Diputación General De Aragón (Accessed 14 May 2020). https://ec.europa.eu/info/f ood-farming-fisheries/key-policies/common-agricultural-policy/cmef/productsand-markets/common-organisation-markets-sheep-and-goatmeat-sector_sk.

AOCS, 2005. Official procedure, approved procedure. Am 5-04. Rapid Determination of Oil/Fat Utilizing High Temperature Solvent Extraction. American Oil Chemistry Society, Urbana, IL.

Bell, R.G., 2001. Meat packaging: protection, preservation and presentation. In: Hui, Y. H., Nip, W.K., Rogers, R.W., Young, O.A. (Eds.), Meat Science and Applications. Marcel-Dekker, USA, pp. 463-490.

Bell, R.G., Hathway, S.C., 1996. The hygienic efficiency of conventional and inverted lamb dressing systems. J. App. Bacteriol. 81, 225-234.

Brocklehurst, T.F., Wilson, P.D.G., 2000. The role of lipids in controlling microbial growth. Grasas Y Aceites 51 (1-2), 66-73.

Brown, T., Chourouzidis, K.N., Gigiel, A.J., 1993. Spray chilling of lamb carcasses. Meat Sci. 34, 311-325.

Clemens, R.M., Adam, K.H., Brightwell, G., 2010. Contamination levels of Clostridium estertheticum spores that result in gaseous spoilage of vacuum-packaged chilled beef and lamb meat. Lett. App. Microbiol. 50, 591-596.

Cruz, B.C., Cerqueira, J., Araújo, J., Gonzales-Barron, U., Cadavez, V., 2019. Estudio de las características de crecimiento de corderos de las razas churra galega-bragançana y bordaleira-de-entre-Douro-e-minho. XVIII Jornadas Sobre Producción Animal (Zaragoza, Spain, May 7-8). Asociación Interprofesional para el Desarrollo Agrario, Spain, pp. 66-68. In Spanish.

De-Arriba, R., Sánchez-Andrés, A., 2014. Production and productivity in Eastern and Western European sheep farming: a comparative analysis. Liv. Res. Rural Develop. 26 (4), 66 (Accessed 14 May 2020). http://www.lrrd.org/lrrd26/4/arri26066.htm.

Drosinos, E.H., Board, R.G., 1995. Microbial and physicochemical attributes of minced lamb: sources of contamination with pseudomonads. Food Microbiol. 12, 189-197.

Eurostat, 2019. Agriculture, Forestry and Fishery Statistics, 2019 edition. European Commission. https://doi.org/10.2785/79876 (Accessed 10 May 2020). https://ec. europa.eu/eurostat/en/web/products-statistical-books/-/KS-FK-19-001.

Gadd, G.M., 2010. Metals, minerals and microbes: geomicrobiology and bioremediation. Microbiology 156, 609-643.

Gill, C.O., 2004. Spoilage, factors affecting - microbiological. In: Jensen, W. (Ed.), Encyclopedia of Meat Science. Elsevier, Oxford, pp. 1324-1330.

Grau, F.H., 1980. Inhibition of the anaerobic growth of Brochothrix thermosphacta by lactic acid. App. Environ. Microbiol. 40 (3), 433-436.

ISO, 1978. Determination of nitrogen content. ISO 937:1978 standard. International Standards Meat and Meat Products. International Organization for Standardization, Geneve, Switzerland.

ISO, 1997. Determination of moisture content. ISO 1442:1997 standard. International Standards Meat and Meat Products. International Organization for Standardization, Geneve, Switzerland.

ISO, 1998. Determination of ash content. ISO 936:1998 standard. International Standards Meat and Meat Products. International Organization for Standardization, Geneve, Switzerland.

Jones, R.J., 2004. Observation on the succession dynamics of lactic acid bacteria populations in chill-stored vacuum-packaged beef. Int. J. Food Microbiol. 90, 273-282.

Lawson Handley, L.-J., Byrne, K., Santucci, F., Townsend, S., Taylor, M., Bruford, M.W., Hewitt, G.M., 2007. Genetic structure of European sheep breeds. Heredity 99, $620-631$.

Martineli, T.M., Rossi Junior, O.D., Cereser, N.D., Cardozo, M.V., Fontoura, C.L., Perri, S. H.V., 2009. Microbiological counting in lamb carcasses from an abattoir in São Paulo, Brazil. Ciência Rural Santa Maria 39 (6), 1836-1841.

Mendelsohn, R., 2003. The challenge of conserving indigenous domesticated animals. Ecol. Econ. 45, 501-510.

Mills, J., Donnison, A., Brightwell, G., 2014. Factors affecting microbial spoilage and shelf-life of chilled vacuum-packed lamb transported to distant markets: a review. Meat Sci. 98, 71-80.

Pateiro, M., Lorenzo, J.M., Díaz, S., Gende, J.A., Fernández, M., Gonzalez, J., Garcia, L., Rial, R.J., Franco, D., 2013. Meat quality of veal: discriminatory ability of weaning status. Span. J. Agric. Res. 4, 1044-1056.

Prates, J.A.M., 2000. Maturação da carne dos mamíferos: caracterização geral e modificações físicas. Revista Portuguesa de Ciências Veterinárias 95 (533), 34-41. In Portuguese.

Prieto, M., García, M.L., García, M.R., Otero, A., Moreno, B., 1991. Distribution and evolution of bacteria on lamb carcasses during aerobic storage. J. Food Prot. 54 (12), 945-949.

Sauter, E.A., Jacobs, J.A., Parkinson, J.F., Ercanbrach, S.K., 2006. Effect of carcass weight and fat thickness of lamb carcasses on surface bacteria counts. J. Food Scie. 44 (5), 1430-1431.

Sierra, M.L., Gonzalez-Fandos, E., Garcia-Lopez, M.L., Fernandez, M.C.G., Prieto, M., 1995. Prevalence of Salmonella, Yersinia, Aeromonas, Campylobacter, and coldgrowing Escherichia coli on freshly dressed lamb carcasses. J. Food Prot. 58 (11), 1183-1185.

Statista, 2020. Statistics and Facts on Farming (Accessed 14 May 2020). https://www.st atista.com/markets/421/topic/495/farming/.

Wang, T., Guo, H., Zhang, H., Ren, F., Zhang, M., Ge, S., Luo, H., Zhao, L., 2019. Dynamics of bacterial communities of lamb meat packaged in air and vacuum pouch during chilled storage". Food Sci. Anim. Resour. 39 (2), 209-221. 